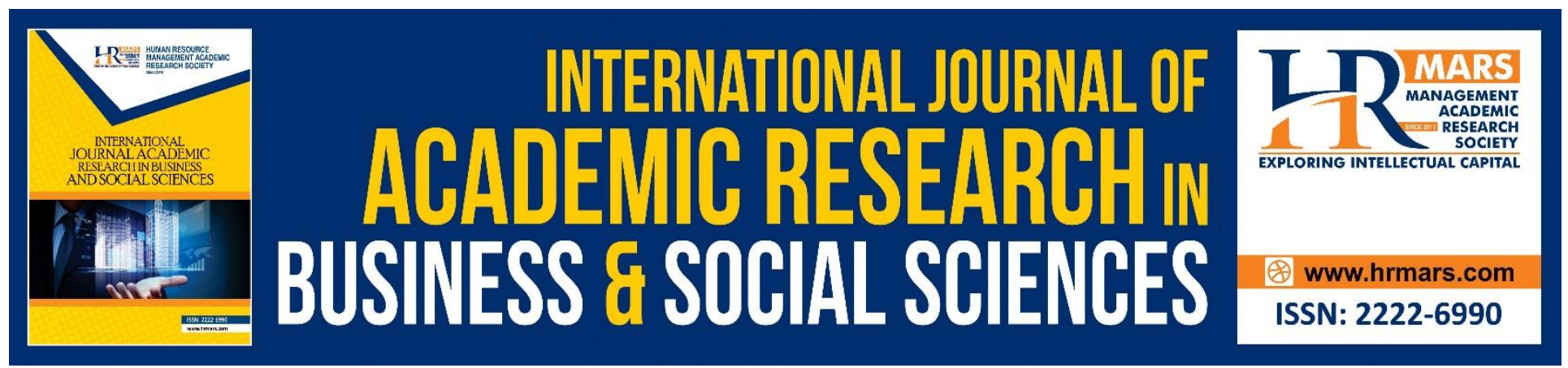

\title{
Instrumental Motivation Orientation vs Integrative among Arabic Language and Literature Diploma Students
}

Kamarul Shukri Mat Teh, Ab Aziz Sulaiman, Nik Mohd Rahimi Nik Yusoff

To Link this Article: http://dx.doi.org/10.6007/IJARBSS/v8-i10/4736 DOI: $10.6007 /$ IJARBSS/v8-i10/4736

Received: 17 Sept 2018, Revised: 21 Oct 2018, Accepted: 26 Oct 2018

Published Online: 31 October 2018

In-Text Citation: (Teh, Sulaiman, \& Yusoff, 2018)

To Cite this Article: Teh, K. S. M., Sulaiman, A. A., \& Yusoff, N. M. R. N. (2018). Instrumental Motivation Orientation vs Integrative among Arabic Language and Literature Diploma Students. International Journal of Academic Research in Business and Social Sciences, 8(10), 308-314.

Copyright: (C) 2018 The Author(s)

Published by Human Resource Management Academic Research Society (www.hrmars.com)

This article is published under the Creative Commons Attribution (CC BY 4.0) license. Anyone may reproduce, distribute, translate and create derivative works of this article (for both commercial and non-commercial purposes), subject to full attribution to the original publication and authors. The full terms of this license may be seen at: http://creativecommons.org/licences/by/4.0/legalcode

Vol. 8, No. 10, 2018, Pg. 308 - 314

Full Terms \& Conditions of access and use can be found at http://hrmars.com/index.php/pages/detail/publication-ethics 


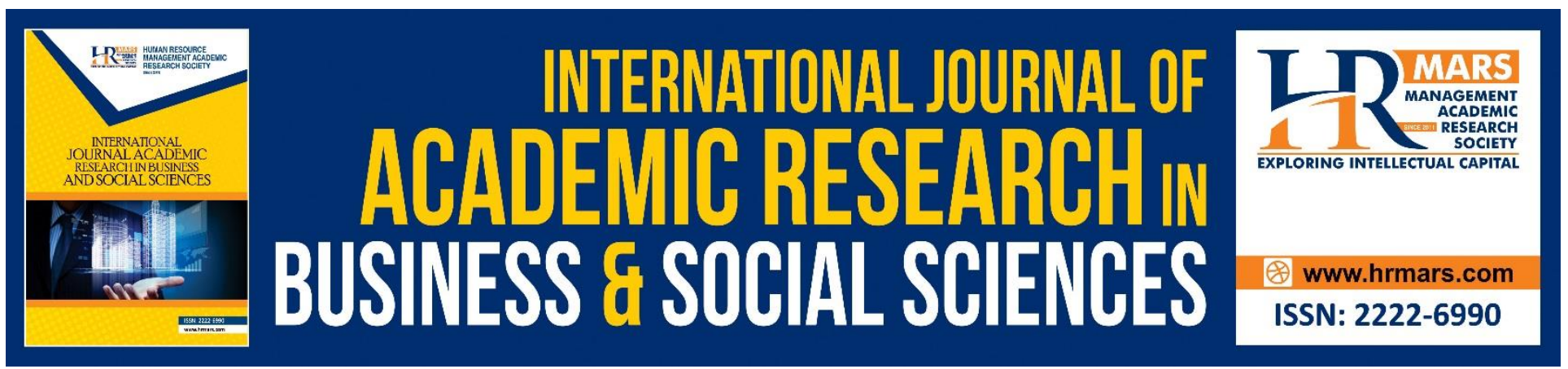

\title{
Instrumental Motivation Orientation vs Integrative among Arabic Language and Literature Diploma Students
}

\author{
Kamarul Shukri Mat Teh, Ab Aziz Sulaiman \\ Faculty of Islamic Contemporary Studies, Universiti Sultan Zainal Abidin, Malaysia \\ Nik Mohd Rahimi Nik Yusoff \\ Faculty of Education, Universiti Kebangsaan Malaysia
}

\begin{abstract}
Motivation is the key and the driver of success in language learning. There are two types of orientations that are often associated with language learning motivation which are integrative and instrumental. This paper aims to identify the dominant type of motivational orientation among Arab language learners. This study survey involves a total of 103 Arabic diploma students at the Terengganu university. They are systematically chosen randomly. Questionnaires have been used to obtain data. It was analyzed using descriptive statistics. The findings showed that integrative motivation orientation was more dominant among the students and almost all of the students were in the integrative motivational orientation level. However, instrumental motivation is still at a high level.
\end{abstract}

Keywords: Language Learning Motivation, Instrumental Orientation, Integrative Orientation, Arabic Language.

\section{Introduction}

Motivation is one of the factors that are often associated with the success of a person in a particular field. It's like a catalyst that speeds up the reactivity of metal in its reaction. It is likewise with learning outcomes. Normally, a student will succeed with excellence when the motivation is high. Low motivation also causes students to become lethargic and quick to give up in their learning.

Such a situation also occurs in the process of language learning. Motivation will raise the spirit of language learners to stay in learning. Certainly, it comes from something that encourages students to learn hard and try to master the target language. Therefore, motivation in the context of 
INTERNATIONAL JOURNAL OF ACADEMIC RESEARCH IN BUSINESS AND SOCIAL SCIENCES Vol. 8, No. 10, Oct. 2018, E-ISSN: 2222-6990 ㄷ 2018 HRMARS

second language learning can be defined as an attempt by language learners as a result of the need and the desire to learn the language (Ellis, 1994).

Gardner (1985) defines the learning motivation of a second language as a stage where one works and strives to learn the language because of his desire to do so and experience the feeling of satisfaction during the activity. He has presented three key components in his definition: business focus, desire for learning, and satisfaction with tasks that are key elements in assessing the level and strength of language learning motivation.

Motivation has been regarded as the key to success in language learning (Dornyei 1990; Gardner 1985; Nunan 1999). It becomes a factor of energy and momentum for language learners so that learning becomes more active and effective. Gardner and Lambert (1972) found that the attitude and motivation of second language learners had significant influence on language learning. If the student is highly motivated, the probability of success is larger and vice versa.

\section{Orientation of Language Learning Motivation}

While studying the literature on motivational learning of language / language learning motivation (LLM), frequent discussions were found on the basis of intrinsic and extrinsic motivation. It is not wrong to argue that the motivation of language learning is based on those two categories but it is still general and does not focus on the 'nature' of second or foreign language learning. Therefore, some language-literate graduates view intrinsic and extrinsic motivation categories as not appropriate to describe language learning motivation.

Master of education such as Gardner and Lambert (1972) have divided the language learning motivation into two types, namely integrative and instrumental motivation. Students are said to have integrative or universal motivation if he learns a second or foreign language with the intention of integrating himself into a language society or getting acquainted with the country of the learnt language. In other words, integrative motivation refers to the positive attitude of the students towards the elements in the target language.

Someone is said to be motivated instrumentally or concrete when the mastery of both languages is aimed at achieving goals other than integration goals, such as passing exams, career enhancements, enabling them to read reading materials in the language and so on. He supports the desire to gain social recognition and economic benefits. Therefore, instrumental motivation refers to functional reasons and usefulness value in language achievement.

It should be emphasized that extrinsic and instrumental motivations are the same but they are not identical. Extrinsic focuses on external causes (for example, working because of money), while instrumental is based on learning goals that are directly related to the target language. Intrinsic and integrative motivation are two different things. Intrinsic relates to something that causes inner self to be fun and cheerful (for example, working because of interest), integrative arises from the selfesteem to be accepted by the target language community (Leaver et al. 2005). In short, instrumental and integrative motivation is more specific to language learning, but extrinsic and intrinsic motivation is seen as a general category of motivation. 
Some studies (example, Gardner \& Lambert 1972) demonstrate integrative motivation to be a major contributor and a key driver of successful language learning compared to instrumental motivation. In the Malaysian context, instrumental motivation is said to be of high potential to catalyse learning a second or foreign language. A good second language proficiency for the excellence of exam results, the continuing of learning opportunities, reference materials in libraries that are mostly in second or foreign languages, and employment opportunities for those who are bilingual are among the factors that can lead to instrumental motivation.

This is illustrated in the issue of bilingual interest in the world of work that has been said since 35 years ago. Former Chief Justice, Tun Mohamad Sufian (Simanjuntak, 1982) states: "Anyone who has the experience of helping find employment for young people knows how limited employment opportunities for graduates who know only one language, whether it's Chinese or Malay ... ". This scenario must be more pronounced when the employment sectors begin to give priority to multilingual individuals who have at least three languages. Therefore, the level of instrumental motivation will definitely increase among the students for the future of their careers.

Studies on Arabic language motivation involving integrative and instrumental orientation are lacking. Most are still studying Arabic language motivation based on intrinsic and extrinsic categories which are considered inappropriate (Leaver et al. 2005). In the Malaysian context, the pattern of motivation of language learning among Arabic language learners is unclear. It is a driving force for a study conducted because the Arabic language is a foreign language in Malaysia where the majority of its population is Muslim and they use the language especially in worship.

There is a study on the type of orientation and the level of Arabic language learning motivation among Arabic language students in Malaysia (Teh et al. 2010). It was conducted on state religious secondary students in Terengganu $(\mathrm{N}=1691 ; \mathrm{n}=460)$. The findings showed that overall motivation was moderate $(M=3.37, S D=0.55)$. At the category level, the respondents tend to show the level of integrative motivation $(M=3.73, S D=0.66)$ higher than the instrumental motivational stage $(M=3.45$, $\mathrm{SD}=0.63$ ), and motivation for learning and language use.

Based on the above problem statement, this study aims to identify the dominant Arabic language learning motivation orientation among Arabic Language and Literature Diploma students at Sultan Zainal Abidin University, Terengganu, Malaysia.

\section{Research Methodology}

Quantitative research using this study survey design was conducted on Diploma students of Islamic Studies Arabic Language and Literature (Bahtera) at Sultan Zainal Abidin University, Terengganu $(\mathrm{N}=173 ; \mathrm{n}=103)$. Samples were selected through systematic random sampling. The data were collected using the modified Affective Survey (Ehrman \& Oxford, 1991) questionnaire. The data was analysed using descriptive statistics.

\section{Finding and Discussion}

Table 1 shows integrative motivation ( $M=4.52, S D=0.44)$ language majors overcome instrumental motivation $(M=3.97, S D=0.46)$. They are all at a high level. The overall motivation of Arabic language majors is also high $(\mathrm{M}=4.24, \mathrm{SP}=0.36)$. 
INTERNATIONAL JOURNAL OF ACADEMIC RESEARCH IN BUSINESS AND SOCIAL SCIENCES Vol. 8, No. 10, Oct. 2018, E-ISSN: 2222-6990 @ 2018 HRMARS

Table 1: Mean And Standard Deviation LLM of Arabic Diploma Students ( $N=103)$

\begin{tabular}{|c|c|c|c|}
\hline Motivation Type & Mean & SD & Interpretation \\
\hline Integrative & 4.52 & 0.44 & High \\
\hline Instrumental & 3.97 & 0.46 & High \\
\hline Total & 4.24 & 0.36 & High \\
\hline
\end{tabular}

This study shows that the orientation of integrative motivation is more dominant among Arabic diploma students than instrumental motivation orientation. It is supported by the findings indicating that the majority of students (96.1\%) have a high level of integrative motivation. Only $3.9 \%$ of the students whose integrative motivation is not high. This is as shown in Table 2. For instrumental motivation, almost $1 / 3$ of students are at a lower level.

Table 2: Number of Students Based on Motivation Level $(\mathrm{N}=103)$

\begin{tabular}{lcc}
\hline \multicolumn{1}{c}{ Motivation Type } & High Level & Lower Level \\
\hline Integrative & 99 & 4 \\
Instrumental & 70 & 33 \\
\hline
\end{tabular}

This study supports the findings of Kamarul Shukri et al. (2010) conducted on Arabic language students in religious high schools, Terengganu. In other words, the integrative motivation orientation of Arabic language students in universities and high schools in Terengganu is more dominant than instrumental motivation. They have a strong desire to integrate with the Arabic culture, community and language materials. In addition, the sample of this study was in Arabic literature. They will always communicate with Arabic history and texts. It is one of the major factors in improving the student's integrative motivation.

In the context of Arabic language learning in Malaysia, which is often associated with the status of foreign language and the scarcity of the environment in language input source, this finding appears to be challenging Dornyei's theory of motivation (1990). According to Dornyei, instrumental motivation contributes towards increasing the motivation of foreign language learners rather than second language learners. This is because the opportunity of foreign language students to interact with target language native speakers and integrate with their community is difficult. This condition makes instrumental motivation higher than integrative motivation among foreign language learners. This view may hold some truth when we look upon the research findings on language learning motivation on language learners of English as a foreign language in Arab Saudi (al-Otaibi 2004) dan Korea (Park 2005).

Consequently, from that, however, arises the question of why this finding is different from Dornyei's language learning motivational theory. The definitions given by scholars to integrative motivational orientation are enough in order to argue as to why they are more dominant and higher in Arabic language learning in Malaysia. Based on substructures in the study instrument, integrative constructs is related to the feelings or responses to Arabic language, language proficiency, culture, 
community and religious encouragement. All of these elements are integration-oriented and interacting with the target language elements. It is derived from the religious factor that the Arabic language becomes a civilization vehicle. Arabic learners in Malaysia learn the language as it has a very strong relationship with religion, worship and preaching. Therefore, it is not surprising that integrative-oriented motivation is stronger and higher than other types of motivation.

The explanation for the above findings was also supported by the study of Al-Khuli (1990) on 42 Arabic language teachers from ten countries attending Arabic language training courses at AlMalik University Su'ud, Riyadh. The study found the purpose of understanding the teachings of Islam, adding knowledge, understanding of Arabic speech, and positive attitude toward Arabs are the most powerful factors that encourage them to learn Arabic rather than to achieve high rankings in society or to get a job. In other words, integrative oriented motivation in Arabic learning is more dominant and influential rather than instrumental orientation and language-learning efforts.

\section{Conclusion}

Integrative orientation motivation needs to be nurtured and dominated because students who demonstrate integrative orientation are more likely to receptive learning that is language acquisition rather than defensive learning that is purely language learning (Krashen 1988). This situation helps language learners to learn actively and effectively either on the inside or outside the classroom. In addition, Oxford \& Shearin (1994) states that integrative motivation is more likely to affect students with levels of intermediate and above. It should be noted that this paper does not deny the importance of instrumental motivation while studying Arabic. In fact, the findings showed that the instrumental motivation of the sample was high. It is still important and worthy of attention when learning Arabic. It is especially important when the desire of the student to excel in his/her study, succeed in work, and to gain recognition overpower any other factors.

\section{Acknowledgement}

The authors would like to acknowledge the Research Management, Innovation and Commercialization Centre (RMIC), Universiti Sultan Zainal Abidin for funding this study Reference number: UniSZA/11/GU (031)\}.

\section{Corresponding Author}

Kamarul Shukri Mat Teh. Faculty of Islamic Contemporary Studies, Universiti Sultan Zainal Abidin. Email: kamarul@unisza.edu.my

\section{References}

Dornyei, Z. (1990). Conceptualizing motivation in foreign-language learning. Language Learning 40: 45-78.

Ehrman, M.E. \& Oxford, R.L. (1991). Affective survey. Arlington, VA: Foreign Service Institute. Ellis, R. (1994). The study of second language acquisition. Oxford: Oxford University Press. Gardner, R.C. (1985). Social psychological aspects of language learning: the role of attitudes and motivation. London: Edward Arnold. 
INTERNATIONAL JOURNAL OF ACADEMIC RESEARCH IN BUSINESS AND SOCIAL SCIENCES

Vol. 8, No. 10, Oct. 2018, E-ISSN: 2222-6990 ㄷ 2018 HRMARS

Gardner, R.C. \& Lambert, W.E. (1972). Attitudes and motivation in second language learning. Rowley, MA: Newbury House.

Teh, K.S.M., Embi, M. A., Yusoff, N.M.R.N. \& Mahamod, Z. (2010). Hubungan tahap motivasi dengan strategi pembelajaran Bahasa Arab dalam kalangan pelajar Sekolah Menengah Agama Terengganu. Jurnal Teknologi (Sains Sosial), 52: 57-67.

Al-Khuli, M.A. (1990). Bacd al-jawanib al-lughwiyyah wa al-taclimiyyah wa al-nafsiyah laday majmuªh min mucalimiyy al-lughah al-carabiyyah li ghayr al-natiqin biha. In Buhuth lughawiyyah wa 'adabiyyah, pp. 111-152. Makkah al-Mukarramah: Jamiacah Umm al-Qura.

Krashen, S.D., (1988). Second language acquisition and second language learning. New York: Prentice-Hall.

Leaver, B.L., Ehrman, M. \& Shekhtman, B. (2005). Achieving success in second language acquisition. Cambridge: Cambridge University Press.

Simanjuntak, M. (1982). Aspek bahasa dan pengajaran. Kuala Lumpur: Sarjana Enterprise.

Nunan, D. (1999). Second language teaching and learning. Massachusetts: Heinle \& Heinle Publishers.

Al-Otaibi, G. N. (2004). Language learning strategy use among Saudi EFL students and its relationship to language proficiency level, gender and motivation. Ph.D. Dissertation. Indiana University of Pennsylvania.

Oxford, R.L. \& Shearin, J. (1994). Language learning motivation: expanding the theoretical framework. The Modern Language Journal 78 (1): 12-28.

Park, S.H. (2005). Language learning strategies and the relationship of these strategies to motivation and English proficiency among Korean EFL students. Ph.D. Dissertation. University of Kansas. 